\title{
Kovárványcsíkok képződése a Nyírség homoktalajában
}

\author{
${ }^{1}$ Kalmár János, ${ }^{1}$ Kuti László, ${ }^{2}$ KÁTAI János, ${ }^{3}$ FigLer Renáta és ${ }^{3}$ FüLEKY \\ György
}

${ }^{1}$ Magyar Földtani és Geofizikai Intézet, Környezetföldtani Osztály, Budapest

${ }^{2}$ Debreceni Egyetem, Mezőgazdaság-, Élelmiszertudományi és

Környezetgazdálkodási Kar, Agrokémiai és Talajtani Intézet, Debrecen

${ }^{3}$ Szent István Egyetem, Mezőgazdaság-, és Környezettudományi Kar, Környezettudományi Intézet, Gödöllő

\section{Bevezetés}

A Nyírség és Románia északnyugati határvidékének jellegzetes képződménye a helyenként $10 \mathrm{~m}$ magasságot is elérő buckákba rendeződő eolikus homok. Itt jelennek meg a kovárványként leírt, több tíz $\mathrm{cm}$ vastagságú, vöröses barna színü, lencsés vagy szabálytalan alakú betelepülések, természetes és főleg mesterséges feltárásokban, útbevágásokban.

Mivel az eolikus homok jelenleg és feltételezhetően a (földtani) múltban is talajfunkcióval rendelkezett, indokoltnak látszik e betelepülések vizsgálata nem csak egy földtani profilú (külföldi) szakfolyóiratban publikált (KUTI et al. 2017) ásvány-kőzettani és szedimentológiai vonatkozásban, de talajtani szempontokat is figyelembe véve. Ezért tartjuk indokoltnak, hogy az általunk végzett kutatások eredményei magyar nyelven is elérhetők legyenek, főleg a talajképződés szemszögéből nézve.

Úgy a magyar, mint a külhoni szakirodalomban a kovárványnak, ill. a „wetting front"-hoz tartozó jelenségnek helyet adó közege az eolikus, ill. fluvioeolikus homokakkumuláció; esetenként a dominánsan alleuritos szemcseösszetételü talajszelvényekben is megjelenik (JOHNSON et al. 2008, KEMP et al., 1989). Hasonló, de litifikált betelepülések követhetők a földtani múlt számos, eredetileg fluvioeolikus homokkő-szelvényeiben, mint pl. a DK-szaharai Nubiai Formációban (KLITSCH et al., 1979).

Ugyancsak megegyeznek a kutatók abban, hogy a kovárványszintek egymással párhuzamosan helyezkednek el a homoktestek réteges szerkezetében (KÁDÁR, 1951; BORSY, 1961; BERG, 1984; STEFANOVITS, 1953, 1999; ILYUSHEV et al., 2012). Elfogadott tény, hogy a kovárvány szintek a már kialakult homokfelhalmozódásban keletkeztek és követik annak a morfológiáját (BORSY, 1961; BERG, 1984, HORVÁTH, 1985; LOVÁSZ, 1997; BURÓ, 2016).

A kutatók a kovárványszintek kialakulását meglehetősen tág időhatárok közt feltételezik. KRIVÁN (1958) és MAROSI (1966) a jéglencsés pleisztocén tundrákhoz köti a kovárványképződést, míg BORSY (1961) az utolsó glaciális nyír-fenyő

Postai cím: FÜlEKY GYÖRGY, Szent István Egyetem, Mezőgazdaság-, és Környezettudományi Kar, Környezettudományi Intézet, 2100 Gödöllö, Páter Károly u. 1.

E-mail: fuleky.gyorgy@mkk.szie.hu

A cikk a Creative Commons Attribution-Non Commercial 4.0 License rendelkezései szerint publikált Open Access közlemény. 
korhoz, és így gondolja JANKOVSKI (2002) és részben GRUBE (2002) is. A holocén különböző periódusaiban megjelent kovárványszinteket PRUSINKIEWICZ et al. (1998), ILYUSHEV et al. (2012), KALMÁR et al. (2017) jelezi és BURÓ (2015) geokronológiai módszerekkel dokumentálja.

Ugyancsak változatosak és ellentmondásosak a kovárványképződés mechanizmusával kapcsolatos hipotézisek is. A kutatók egy része (BORSY, 1961; KeMP és MCINTOSH, 1979; BERG, 1984; STEFANOVITS, 1999) a megjelenő finomréteges, lamelláris szerkezetből kiindulva a csapadékvíz által beszállított — és a finomabb szemcsés rétegekben kicsapódó — vaskolloidokat tartják fontosnak (DiJKerman et al., 1967; KeMP és MCINTOSH, 1979, STEFAnOVITS, 1963), míg TORRENT et al. (1980) és PRUSINKIEWICZ et al. (1998) az illuviális beszivárgásra utalnak. A nagyobb finomszemcse frakció részaránya magyarázható ez úton, de SCHAETZL (2001) vizsgálatai a homoktestre felhordott finomszemü lepel bevonatot, KILIBARDA et al. (2008) a homokba „,bevegyülö”, görgetett agyaggöbecseket is megemlít. A vaskolloidok mozgása és a közeg pH-értéke közötti összefüggés BORSY-nál (1961), STEFANOVITS-nál (1963) és BURÓ-nál (2016) kerül kihangsúlyozásra. ILYUSHEV et al. (2012) esetében a pH emelkedése okozta a deltahomokban megjelenő vasoxidos csíkokat. Itt kell megemlíteni STEFANOVITS (1963) hipotézisét, a Liesengang-gyürükhöz hasonló kolloidális közegekben gyakori diffúziót.

Habár az idézett kutatóknál is felmerül a kovárványképződés és a talajszelvényekben lezajló biológiai folyamatok kapcsolata, ezt sem DIJKERMAN et al., 1967, sem KEMP és MCINTOSH (1979) sem BERG (1984) nem tartják lényegesnek és STEFANOVITS (1999), ill. BURÓ (2016) is csak megemlíti. Ezért tartottuk fontosnak, hogy az általunk vizsgált kovárvány-szelvényben a talajbiológiai folyamatokra is tekintettel legyünk.

Mivel a célunk végső soron a kovárványszintek genetikájának meghatározása volt, a feltárások és a minták vizsgálata során a következő kérdésekre kívántunk választ kapni:

1. Melyek a buckát képező homok folyóvízi és/vagy eolikus bélyegei?

2. Mi a különbség a kovárványszintek és a környező homok összetétele között?

3. Léteznek-e a kovárványban a vas oxi-hidroxidok mozgására utaló jegyek?

4. Találhatók-e összefüggések a vasásvány-akkumuláció és a talajvízszint mozgása között?

5. A vasásvány felhalmozódást felszínközeli (talajtani) vagy mélységi (földtani) folyamatok okozták?

\section{Vizsgálati anyag és módszer}

A vizsgálat anyaga Magyarország északkeleti részét alkotó eolikus üledékből származik. A Debrecentől 15 km-re északra fekvő Tamáspuszta (1. ábra) (47 38 '4671' ' és $21^{0} 52^{\prime} 1756$ ') és tágabb környéke a nyírségi homok tipikus előfordulása, ahol a késő pleisztocén során az Ös Tisza hordalékából kifújt homokbuckákba, ÉK-DNy irányú dünékbe rendeződve folyamatosan lefedte, 
betakarta a Szilágysági Dombvidék peremterületén kifejlődött síkság folyóvízi, vályogos-agyagos üledékeit.

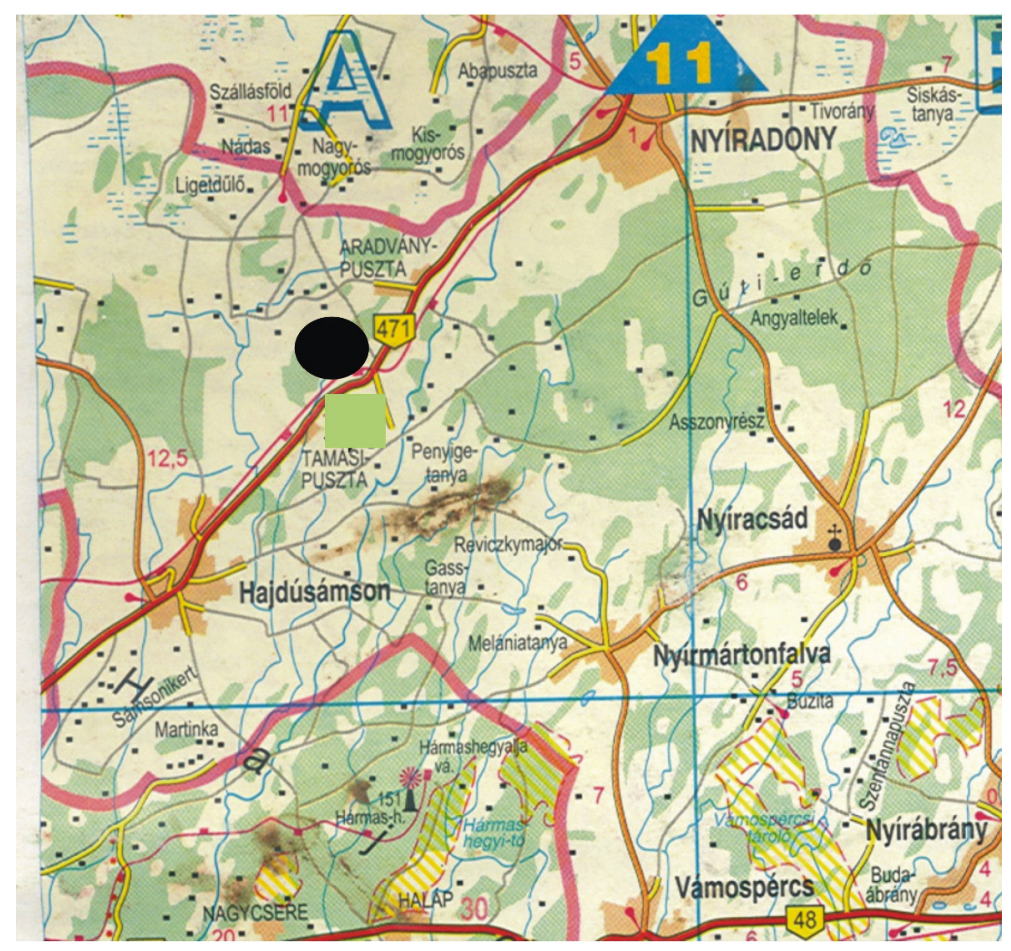

1. ábra

A feltárás helye $(\bullet)$

A felszínközeli üledékek jelentős része a 10-25 m vastagságban kifejlődött, Würm végén képződött futóhomok. A homok fő mozgási fázisa a késő glaciálisban volt. A holocén szárazabb időszakában a homok mozgása folytatódott (BULGĂREANU, 1968), így az országhatáron túl bronzkori településeket fedett le (DUMITRAŞCU, 1974), ill. helyenként a közelmúltban is folyamatban volt.

A Nyírségben viszonylag nagy területeket fed a nyírvíz-laposokhoz kapcsolódó 1-5 m vastagságú folyóvízi homok. Ezek kialakulása több szakaszban, a holocénben történt (DövÉNYI 2010, SOMOGYI és MAROSI, 1990).

A területen végzett térképező fúrások alapján (KERÉK et al., 2001) a pleisztocén folyóvízi finom szemü üledék a felszín alatt $8-10 \mathrm{~m}$ mélységben van jelen. A homokbuckák közötti mélyedéseket helyenként szerves anyagban gazdag lápi üledékek töltik ki, egy ÉK-DNy irányú ér-rendszer részeként (KALMÁR és VATAI, 1994). A vizsgált területen a talajvíz szintje 128-132 m tszf.-nél jelenik meg, 5-10 m-el a felszín alatt (KUTI et al., 2001). Ezen a területen a KÁDÁR (1957) által kovárványként leírt, vöröses színü betelepülések a buckák felső részében, általában 1-2 m-re a felszín alatt láthatók. 
Tamáspuszta a Nyírségben helyezkedik el Nyíradony város részeként. A térség tengerszint feletti magassága 130-162 m, jellege szélhordta homokkal fedett hordalékkúp-síkság. Jelenleg évi 2000 óra napsütést élvez a vidék, az évi középhőmérséklet $9,6-9,8{ }^{\circ} \mathrm{C}$. Az évi csapadékösszeg $560-580 \mathrm{~mm}$, de a keleti területeken a $600 \mathrm{~mm}-\mathrm{t}$ is meghaladja (SOMOGYI és MAROSI 1990). A talajvízszintet Nyíracsád környékén 4-6 m között, a laposokban 2-4 m között találjuk. A talajvíz kémiai jellege Nyíradony-Nyírábrány között nátrium-, máshol kalcium-, magnézium-hidrogénkarbonátos.

A kistáj a nyírségi flórajárás része. Legjellegzetesebb erdőtársulásai a tölgykőris-szil ligeterdők, a pusztai tölgyesek és a gyöngyvirágos tölgyesek. Jelentős felületet borítanak a homokpuszta-gyepek. A mozaikos kistájat lényegében a homoktalajok uralják (80\%). A kovárványos barna erdőtalajok 8\%-ot tesznek ki.

A kovárványszintek tanulmányozására a Debrecentől 15 km-re lévő tamáspusztai homokbánya ÉK-i rézsűjébe vágott szelvényen került sor. A szelvény egy $3 \mathrm{~m}$ magas bucka gerincét tárta fel, több kovárványszinttel. Az anyagvizsgálat során talajtani, mikrobiológiai és ásványtani vizsgálatokat végeztünk.

A tamáspusztai feltáráson talajtani vizsgálatok céljából 2008-ban kétféle módon vettünk mintákat, egyfelől a szelvény falát $50 \mathrm{~cm}$ vastagon letisztítva, (külső fal), másfelöl a dombon $\mathrm{kb} .4 \mathrm{~m}^{2}$-es felületet nyitottunk meg és lefelé haladva mintáztuk meg a homokdombot (felület) (FIGLER, 2010). A szelvény falából és a felületböl vett talajmintákban meghatároztuk a kötöttséget $\left(\mathrm{K}_{\mathrm{A}}\right)$, a $\mathrm{pH}-\mathrm{t}\left(\mathrm{pH}_{\mathrm{KCl}}\right.$, és $\left.\mathrm{pH}_{\mathrm{H} 2 \mathrm{O}}\right)$, a humusztartalmat, a mechanikai összetételt, az oxalát, illetve ditionit oldható $\mathrm{Fe}$ tartalmat (BUZÁs 1988). Az e módon vett minták helye és jellege, valamint a genetikai szintje az 1. táblázatban látható. Felületi mintáknál, illetve a külső falnál közel azonos szintbeli értékek is előfordulnak, tekintettel a kovárványrétegek hullámos voltára.

A mikroorganizmus populációk vizsgálatakor meghatároztuk az összes baktériumszámot (húsleves-agaron), a mikroszkopikus gombák mennyiségét (pepton-glükóz-agar táptalajon) vizes-talaj szuszpenzióból, lemezöntéssel (SzEGI, 1979).

A talajok mikrobiológiai aktivitásának megállapításához a képződött széndioxidot mértük laboratóriumi körülmények között (SZEGI, 1979) és a mikrobiális biomassza C értékét fumigációs-extrakciós eljárással (VANCE et al, 1987).

A talajminták ásványi fázisán megvizsgáltuk az ásványi összetételt, a homokszemcsék morfológiai sajátosságait, a szemcseméret eloszlást, az üledék szerkezetét-szövetét, valamint megvizsgáltuk a talajkémiai vizsgálatok ásványtani vonatkozásait (KINSLEY \& DORNKAMP 1973, MOLNÁR 1981).

A minták ásványi összetételét a feltárás 1-8. mintáin vizsgáltuk. A folyós homok esetében binokuláris, max. 25x nagyítású mikroszkóppal, a kötött rögökön és a feltárásból vett Cube-1 (kovárvány, 85-90 cm) és Cube-2 (köztes homok, 90-95 $\mathrm{cm}$ ) monolitokon optikai módszerrel, polarizációs mikroszkóppal vizsgáltunk, vékony és felületi csiszolatokban. A finom frakció ásványtani összetételét a röntgendiffrakciós analízis eredményezte. Pásztázó elektronmikroszkópos (SEM) vizsgálataink a szemcsék morfológiájára és a finom frakció ásványainak a sajátosságaira adtak információt. 
A rendelkezésünkre álló kovárvány mintákon, egy köztes homokrétegből és a két monolit (Cub-1 és Cub-2) anyagából a Magyar Âllami Földtani Intézet kémiai laboratóriumában királyvizes kioldással ICP-MS táp-és nyomelem-vizsgálatot végeztünk.

\begin{tabular}{|c|c|c|c|c|}
\hline $\begin{array}{l}\text { Minta } \\
\text { száma } \\
\text { (1) }\end{array}$ & Helyzet (2) & $\begin{array}{l}\text { Mélység, } \\
\text { cm (3) }\end{array}$ & Minta leírása (4) & $\begin{array}{l}\text { Genetikai } \\
\text { szint }\end{array}$ \\
\hline 1 & Külső fal (a & $5-20$ & Nedves homok (d & $\mathrm{A}_{1}$ \\
\hline 2 & Külső fal & $30-35$ & $\begin{array}{l}\text { Homok a legfelső kovárványcsík és első } \\
\text { kovárvány réteg között (e }\end{array}$ & $\mathrm{A}_{2}$ \\
\hline 3 & Külső fal & $35-50$ & Első kovárványréteg (f & $1 \mathrm{C} / \mathrm{Bt}_{1}$ \\
\hline 4 & Külső fal & $55-62$ & Két kovárványréteg közötti homok (g & $1 \mathrm{C}$ \\
\hline 5 & Külső fal & $62-75$ & Második kovárványréteg (h & $1 \mathrm{C} / \mathrm{Bt}_{2}$ \\
\hline 6 & Külső fal & $75-90$ & Második kovárványréteg alatti homok (i & $1 \mathrm{C}$ \\
\hline 7 & Külső fal & $90-100$ & Harmadik kovárványréteg $(\mathrm{j}$ & $1 \mathrm{C} / \mathrm{Bt}_{3}$ \\
\hline 8 & Külső fal & $100-110$ & Harmadik kovárványréteg alati homok (k & $1 \mathrm{C}$ \\
\hline 9 & Külső fal & $120-180$ & Harmadik kovárványréteg alati homok & $1 \mathrm{C}$ \\
\hline 10 & Külső fal & $180-250$ & Harmadik kovárványréteg alati homok & $1 \mathrm{C}$ \\
\hline 11 & Fúrás $(\mathrm{b}$ & $250-300$ & Rozsdás homok (1 & $2 \mathrm{C}$ \\
\hline 12 & Fúrás & $390-500$ & Szürke homok (m & $3 \mathrm{C}$ \\
\hline 13 & Felület (c & $55-62$ & Két kovárvány közötti homok (n & $1 \mathrm{C}$ \\
\hline 14 & Felület & 55 & Kovárvány (o & $1 \mathrm{C} / \mathrm{Bt}_{1}$ \\
\hline 15 & Felület & $40-45$ & Kovárvány & $1 \mathrm{C} / \mathrm{Bt}_{1}$ \\
\hline 16 & Felület & $35-40$ & Két kovárványréteg közötti homok & $1 \mathrm{C}$ \\
\hline 17 & Felület & $28-30$ & Kovárvány & $1 \mathrm{C} / \mathrm{Bt}_{1}$ \\
\hline 18 & Felület & 30 & Humuszos folt & $1 \mathrm{C}$ \\
\hline 19 & Felület & $25-30$ & Felső kovárvány folt & $1 \mathrm{C} / \mathrm{Bt}_{1}$ \\
\hline
\end{tabular}

\section{1. táblázat}

Tamáspusztai talajminták helyzete, jellege és genetikai szintje

\section{Vizsgálati eredmények és értékelésük}

\section{Morfológiai vizsgálatok}

Első eredmények a feltárásokon végzett észlelések során jelentek meg. Így a $2 \times 2$ méteres felületen $20 \mathrm{~cm}$-ig enyhén nedves humuszos réteg volt, majd $25 \mathrm{~cm}$ alatt rozsdásszínü foltokban jelent meg a vasoxid. $25-30 \mathrm{~cm}$ közt kompakt, tömődött 
vörösbarna kovárvány darabok tüntek föl (17. minta), de emellett ennél vékonyabb vörös (19. minta) és humuszfoltok (18. minta) is megjelentek. A $25-30 \mathrm{~cm}$ mélyen látható humuszos foltok elképzelhető, hogy a gyurgyalag fészkek behordott anyagából képződtek. A külső falon a fészkek mindig a száraz porlódó homokban jönnek létre, a felső kovárványcsíkok között, de a mélyebben lévő kovárványcsíkok között is. Körülbelül $50 \mathrm{~cm}$ mélységben tömödöttebb rétegek alkotják a kovárványréteget különböző vastagságban, ahol ezek több $\mathrm{cm}$ vastagságú laminákból állnak. A tömbök és kovárványfelületek szakadozott-gyürt elhelyezkedésben vannak és gyúrás hatását mutatják. Köztük homokkitöltés található, ami néha kovárvány darabkákat tartalmaz (2. ábra). A kovárvány élesen megkülönböztethető, mivel nedvesebb, tömödöttebb, vörösesbarna árnyalattal különül el.

A déli falon $20 \mathrm{~cm}$ mélységig beázott, alatta száraz homok van. Innen kezdődnek a kovárványcsíkok. A legfelső kovárványcsík a száraz homokban $2 \mathrm{~mm}$ vastagságú, hullámos vonalban van a fal bal oldalán. A jobb oldalon a vékony kovárványcsík alatt sárgás, vöröses-barnás száraz homokréteg van a következő kovárványcsíkig, amely körülbelül $40 \mathrm{~cm}$-nél jelenik meg. Fölötte fehéres a homok. Ahol a száraz szürkésfehér homok mélyebbre hatol — körülbelül 50-60 cm-re ott a kovárványcsík is vékony szakadozott a fal közepén. A falakon látható kovárványcsíkok mindig 3D kiterjedésủek és többé-kevésbé tömbökre estek szét. $120 \mathrm{~cm}$-ig voltak gyakoriak a kovárványcsíkok, majd $250 \mathrm{~cm}$-nél vékony humuszos csík tünt fel, alatta $30 \mathrm{~cm}$ vastagon rozsdás homok volt (3. ábra)

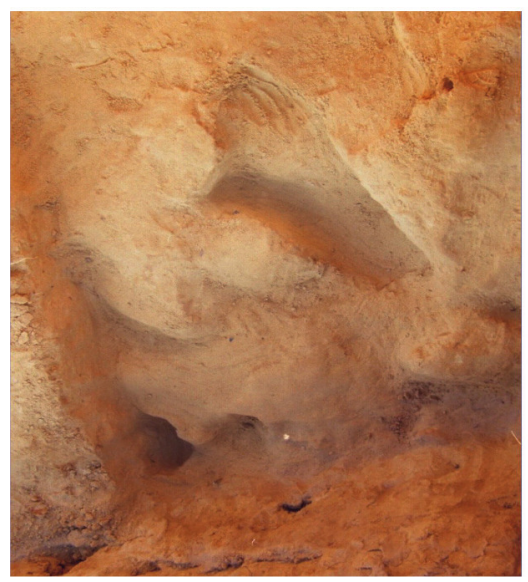

2. ábra

A megnyitott felület $\sim 50 \mathrm{~cm}$ mélységben

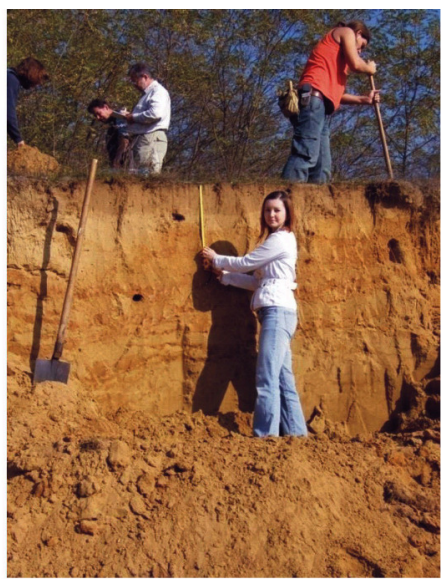

3. ábra

A feltárt szelvény

A fúrások anyagát megvizsgálva azt tapasztaltuk, hogy $390 \mathrm{~cm}$-nél szürke és a mélységgel egyre nagyobb nedvességtartalmú homok jelent meg, melyben rozsdafoltos, 1-2 mm vastag csíkok voltak láthatóak, a $300 \mathrm{~cm}$ alatti sárgásszürkésbarna vegyes rétegben is vasmozgás (glejes) nyomai láthatók. 


\section{Talajtani vizsgálatok}

A vizes pH értékek 5,40- 6,82 között változnak a szelvényben, így a gyengén savanyú kategóriába esnek. A legmélyebb terület $(12$, minta, 390-500 cm) már a közömbös kategóriába esik, a felszínhez legközelebbi rész pedig (1. minta, 5-20 $\mathrm{cm}$ ) a savanyú kategóriába. A szelvény vizes $\mathrm{pH}$ értékei megfelelnek a kovárvány képződésnek, a pH értékeknek ugyanis 4,5- 6,5 között kellene ingadozniuk (BORSY, 1961).

$\mathrm{Az}$ általunk vizsgált szelvényben a három kovárvány-rétegben és a felszín közelében vékony kovárványcsíkokban (17. és 19. minta). 5,85 - 6,78 közötti a $\mathrm{pH}_{\mathrm{H} 2 \mathrm{O}}$ értéke, ahol az előbbi viszonylag alacsony $\mathrm{pH}$-nak számít a szelvényben. Ha azonban megvizsgáljuk közvetlen környezetének $\mathrm{pH}$ értékeit (1. és 18. minta, $\mathrm{pH}$ 5,40 illetve $\mathrm{pH} 5,72$ ) látjuk, hogy azok értékei alacsonyabbak, és ez magyarázza a vékony csík kialakulását, amelynek ezekhez képest magasabb a pH-ja. Ugyanez elmondható a 17. mintáról is, amely ugyanúgy a felső vékony kovárványból lett véve. A három vizsgált kovárványréteg (3., 5., 7. minták) látszólag alátámasztja BORSY elméletét. Az első réteg $15 \mathrm{~cm}$ vastag, 6,00 a pH-ja; a második $13 \mathrm{~cm}$ vastag, $\mathrm{pH}-\mathrm{ja}$ 6,39; a harmadik pedig $10 \mathrm{~cm}, 6,40$ a pH-ja. Ahogy nő a $\mathrm{pH}$, úgy csökken a csíkok vastagsága. Azt is meg lehet figyelni, hogy a kovárványos minták pH-ja általában kisebb, mint az alatta, illetve felette lévő homoké.

A vizsgált szelvény a kis humusztartalmú talajok közé tartozik, hiszen a humusztartalom mindenhol $1 \%$ alatt marad, sőt $0,44 \%$ a legmagasabb érték. Ez jellemző a recens kovárványos barna erdőtalajokra, amelyeknek a humuszanyagtartalma ritkán haladja meg a $2 \%$-ot.

A vizsgált fal humuszanyag-tartalma nagyrészt a felső $60 \mathrm{~cm}$-ben található, azonban itt is csak azokban a mintákban jelenik meg, amelyek nem tartalmaznak kovárványt. Ezek az 1., 18., 2., 16. és 4. minták (2. táblázat). A felszíntől a mélyebb rétegek felé csökken a humusztartalom, csupán a 16 . minta $(35-40 \mathrm{~cm})$ értéke kiugró 0,44\%-al. $60 \mathrm{~cm}$ alatt már egyáltalán nincs a talajban mérhető humusztartalom, csupán a 10. mintában jelenik meg $(0,31 \%)$, ahol a szelvényben humuszos csíkot találtunk. A kovárványos rétegekben egyáltalán nem található humusz, vagy csak nagyon kis mennyiségben, mint a 3 . és 15 . mintában $(0,11 \%$ és $0,13 \%)$. Mindkét minta az első kovárványrétegből való.

Ugyanez a tendencia jól látható, ha csak az agyag frakciót vizsgáljuk. A kovárványos mintákban mindenhol 2,4\%, vagy e fölött van az agyagfrakció részaránya, míg a nem kovárványos mintákban, ezen érték alatt marad, eltekintve a két kiugró értéktől a 4-es és 13-as minta esetében (4,4\% illetve 6,4\%). Ezzel BorSY elmélete is igazoltnak tünik, miszerint a $0,1 \mathrm{~mm}$-nél kisebb szemcsékből a barna szalagok majdnem kétszer annyi agyagfrakciót tartalmaznak, mint a homokréteg (BORSY 1961).

Mindezek alapján látható, hogy a tamáspusztai kovárványképződés feltételei megegyeznek a korábbi hazai tapasztalatokkal, mind a $\mathrm{pH}$, mind a mechanikai összetétel vonatkozásában. Fontos megjegyezni, hogy a humusztartalom a kovárványrétegekben kisebb az alatta és felette található homok humusztartalmánál. 
Ez a tény további következtetések levonását teszi lehetővé, vagyis azt, hogy a vasoxihidroxid képződés a mikrobák intenzív szerves-anyag bontását igényelte.

\begin{tabular}{|c|c|c|c|c|c|c|c|c|c|c|c|}
\hline \multirow[b]{2}{*}{$\begin{array}{l}\text { Minta } \\
\text { jele } \\
(1)\end{array}$} & \multirow[b]{2}{*}{$\begin{array}{l}\text { Mélység, } \\
\text { cm (2) }\end{array}$} & \multirow{2}{*}{$\begin{array}{l}\text { Arany } \\
\text { féle } \\
\text { kötött- } \\
\text { ség, } \mathrm{K}_{\mathrm{A}} \\
\text { (3) }\end{array}$} & \multicolumn{2}{|c|}{$\mathrm{pH}$} & \multirow[b]{2}{*}{$\begin{array}{l}\mathrm{Hu}- \\
\text { musz, } \\
\%(6)\end{array}$} & \multicolumn{3}{|c|}{ Mechanikai összetétel } & \multicolumn{3}{|c|}{$\mathrm{Fe}, \mathrm{mg} / \mathrm{kg}$} \\
\hline & & & $\begin{array}{l}\mathrm{H}_{2} \mathrm{O} \\
\text { (4) }\end{array}$ & $\begin{array}{c}\mathrm{KCl} \\
(5)\end{array}$ & & $\begin{array}{l}\text { Homok, } \\
\%(7)\end{array}$ & $\begin{array}{l}\text { Iszap, } \\
\%(8)\end{array}$ & $\begin{array}{c}\text { Agyag, } \\
\%(9)\end{array}$ & $\begin{array}{c}\text { Oxalát } \\
\text { oldható } \\
\text { (10) }\end{array}$ & $\begin{array}{c}\text { Ditonit } \\
\text { oldható } \\
\text { (11) }\end{array}$ & $\begin{array}{c}\text { Oxalát/ } \\
\text { ditionit } \\
\text { (12) }\end{array}$ \\
\hline 1 & $5-20$ & 25 & 5,40 & 3,85 & 0,33 & 91,6 & 6,0 & 2,4 & 472 & 434 & 1,09 \\
\hline 19 & $25-30$ & 25 & 5,85 & 4,42 & 0,01 & 93,6 & 4,0 & 2,4 & 462 & 456 & 1,01 \\
\hline 17 & $28-30$ & 24 & 5,95 & 4,30 & 0,01 & 79,8 & 13,8 & 6,4 & 970 & 1341 & 0,72 \\
\hline 18 & 30 & 25 & 5,72 & 4,21 & 0,27 & 90,0 & 9,6 & 0,4 & 492 & 462 & 1,07 \\
\hline 2 & $25-35$ & 24 & 5,90 & 4,06 & 0,15 & 93,5 & 6,1 & 0,4 & 482 & 606 & 0,80 \\
\hline 3 & $35-50$ & 25 & 6,00 & 4,66 & 0,11 & 85,8 & 7,8 & 6,4 & 1079 & 1254 & 0,86 \\
\hline 16 & $35-40$ & 25 & 6,00 & 4,98 & 0,44 & 93,6 & 4,0 & 2,4 & 362 & 364 & 1,00 \\
\hline 15 & $40-45$ & 25 & 6,33 & 4,64 & 0,13 & 83,8 & 11,8 & 5,4 & 1043 & 1254 & 0,83 \\
\hline 14 & 55 & 25 & 6,52 & 4,45 & 0,00 & 85,8 & 7,8 & 6,4 & 820 & 1040 & 0,79 \\
\hline 4 & $55-60$ & 25 & 6,56 & 4,85 & 0,09 & 87,8 & 7,8 & 4,4 & 543 & 462 & 1,18 \\
\hline 13 & $22-60$ & 24 & 6,78 & 4,60 & 0,01 & 87,5 & 6,1 & 6,4 & 553 & 485 & 1,14 \\
\hline 5 & $62-75$ & 25 & 6,39 & 5,03 & 0,01 & 81,8 & 9,8 & 8,4 & 831 & 998 & 0,83 \\
\hline 6 & $80-90$ & 25 & 6,50 & 5,32 & 0,01 & 93,6 & 6,0 & 0,4 & 462 & 450 & 1,02 \\
\hline 7 & $90-100$ & 25 & 6,40 & 5,21 & 0,01 & 85,5 & 12,1 & 2,4 & 792 & 719 & 1,10 \\
\hline 8 & $100-110$ & 25 & 6,46 & 5,56 & 0,01 & 95,6 & 4,0 & 0,4 & 432 & 369 & 1,17 \\
\hline 9 & 120 & 25 & 6,22 & 5,68 & 0,01 & 95,6 & 4,0 & 0,4 & 382 & 333 & 1,15 \\
\hline 10 & 180 & 25 & 6,80 & 5,70 & 0,31 & 91,6 & 8,0 & 0,5 & 382 & 333 & 1,15 \\
\hline 11 & $250-300$ & 25 & 5,70 & 5,75 & 0,01 & 92,0 & 5,6 & 2,4 & 432 & 568 & 0,76 \\
\hline 12 & $390-500$ & 25 & 6,82 & 5,87 & 0,01 & 91,6 & 6,0 & 2,4 & 432 & 275 & 1,58 \\
\hline
\end{tabular}

\section{2. táblázat}

A szelvényfalból és felületből vett talajminták kémhatása, humusz- és Fe-tartalma, valamint a mechanikai összetétele mélység szerinti eloszlásban

A magyar talajtani osztályozás szerint a talajt kovárványos barna erdőtalajnak tartjuk, az ennek megfelelő WRB osztályozás szerint Lamellic Luvisol. A kovárványcsíkok jellemzését és képződését a későbbiekben tárgyalva előre jelezzük, hogy nem tartjuk bizonyítottnak a vas- és agyagmozgást, ezért a WRB rendszerben inkább a Lamellic Arenosol osztályozást látjuk indokoltnak.

\section{Mikrobiológiai vizsgálatok}

Talaj-mikroorganizmusok előfordulása és aktivitása szempontjából meghatározó a talaj nedvességtartalma. A vizsgált talajszelvény egyes rétegeinek nedvességtartalma 3-4 tf\% közötti intervallumban változott, amely nagyon csekély, száraznak minősíthető. A vizsgált talaj mikrobiológiai paraméter értékeit a 3. táblázatban mutatjuk be. 


\begin{tabular}{|c|c|c|c|c|c|}
\hline $\begin{array}{c}\text { Minta } \\
\text { jele } \\
(1)\end{array}$ & $\begin{array}{c}\text { Mélység } \\
\mathrm{cm}(2)\end{array}$ & $\begin{array}{c}\text { Összes } \\
\text { csíraszám, } \\
10^{6} / \mathrm{g} \text { talaj (3) }\end{array}$ & $\begin{array}{c}\text { Mikroszkopikus } \\
\text { gombaszám, } \\
10^{3} / \mathrm{g} \text { talaj (4) }\end{array}$ & $\begin{array}{c}\mathrm{CO}_{2} \text { produkció, } \\
\mathrm{mg} / 100 \mathrm{~g} / 10 \text { nap } \\
(5)\end{array}$ & $\begin{array}{c}\text { Mikrobiális } \\
\text { biomassza } \\
\mathrm{C} \mu \mathrm{g} / \mathrm{g}(6)\end{array}$ \\
\hline 1 & $5-20$ & 10,15 & 28,67 & 5,20 & 11,37 \\
\hline 2 & $25-35$ & 1,30 & 15,67 & 6,30 & 9,74 \\
\hline 3 & $35-50$ & 9,70 & 3,70 & 6,33 & 11,37 \\
\hline 4 & $55-60$ & 9,07 & 1,73 & 5,25 & 3,25 \\
\hline 5 & $62-75$ & 8,37 & 0,50 & 4,88 & 4,87 \\
\hline 6 & $80-90$ & 5,18 & 2,50 & 4,28 & 12,99 \\
\hline 7 & $90-100$ & 21,04 & 3,30 & 5,83 & 32,48 \\
\hline 8 & $100-110$ & 1,93 & 1,00 & 5,48 & 17,86 \\
\hline 9 & $120-180$ & 1,78 & 1,00 & 5,88 & 17,86 \\
\hline 10 & $180-250$ & 5,78 & 1,63 & 4,33 & 8,12 \\
\hline 11 & $250-300$ & 0,44 & 1,07 & 6,03 & 3,25 \\
\hline 12 & $390-500$ & 37,85 & 0,33 & 4,33 & 22,73 \\
\hline
\end{tabular}

\section{3. táblázat}

A talajprofil mikroorganizmus populációjának mennyisége és mikrobiológiai aktivitása

A vizsgált talajszelvényben az összes csíraszám értéke $10,15-0,44 \times 10^{6}$ /g között változott. A talaj felszínétől a profil alsó szintjéig csökkent a baktériumok mennyisége, kivéve a 7. és a 12. mintát, ahol 2-szer, ill. 3,5-ször több baktériumot határoztunk meg, mint a felső szintben. A kovárványcsíkokban rendszerint nagyobb csíraszámot határoztunk meg, mint a kovárványcsíkok közötti rétegekben.

Nagyobb mikroszkopikus gombaszámot $\left(28,67-15,67 \times 10^{3} / \mathrm{g}\right)$ a felső két szintben $(5-20 \mathrm{~cm}, 25-35 \mathrm{~cm})$ mértünk. A többi szintben csak néhány ezer mikroszkopikus gombát találtunk $\left(0,33-3,70 \times 10^{3} / \mathrm{g}\right)$.

A talajok széndioxid-termelő képessége szűk intervallumban változott $(4,28$ $6,33 \mathrm{mg} / 100 \mathrm{~g} / 10 \mathrm{nap})$. A 2. és a 3. mintákban nagyobb értékeket mértünk (6, 03 és $6,33 \mathrm{mg} / 100 \mathrm{~g} / 10 \mathrm{nap})$, mint a többi rétegben, kivéve a 11 . mintát $(6,03 \mathrm{mg}$ /100g/10nap).

A mikrobiális biomassza-szén mennyisége 3,25-32,48 $\mu \mathrm{g} / \mathrm{g}$ értékek között ingadozott. A 7., 12., 8., 9. mintákban nagyobb értékeket $(32,48-17,86 \mu \mathrm{g} / \mathrm{g})$, a 4., 5., 10., 11. mintákban pedig kisebb értékeket $(8,12-3,25 \mu \mathrm{g} / \mathrm{g})$ határoztunk meg. A talajmikrobiológiai eredményeket értékelve szembetünő, hogy a 90-100 cm-es és $500 \mathrm{~cm}$-es rétegben nagyobb összes csíraszámot és mikrobiális biomassza-szenet találtunk, mint a többi rétegben. A mikrobiológiai paraméterek közül, a felső szintben csak a mikroszkopikus gomba mutatott nagyobb értéket. 


\section{Ásványtani vizsgálatok}

A minták domináns ásványa a kvarc, 83-94\% részarányban (4. táblázat). A szürke, sárga és tejfehér, metamorf eredetü, csiszolatokban hullámos kioltású kvarc mellett gyakoriak a víztiszta, vulkáni eredetü kvarcszemcsék is.

A földpátok részaránya 4-8\%. Jelen van a gyengén bontott mikroklin, az üde ortoklász, kevés szericitesedett albit és intermedier plagioklász. Szórványos muszkovit, klorit lapocskák, amfibol és járulékos ásványok találhatók (I. tábla, 1 . fotó). Az utóbbiak közül azonosítottuk a metamorf és vulkáni kőzetekre jellemző cirkont, titanitot, rutilt, staurolitot, gránátot, turmalint és epidotot. A felületi csiszolatokban az átlátszó ásványokon kívül a magnetit, az ilmenit és a hematit voltak jelen.

\begin{tabular}{|c|c|c|c|c|c|c|c|c|c|c|c|}
\hline \multirow[b]{2}{*}{$\begin{array}{l}\text { Minta } \\
\text { sz. (1) }\end{array}$} & \multicolumn{7}{|c|}{ Ásványok } & \multirow[b]{2}{*}{$\begin{array}{l}\text { Közet } \\
\text { törme- } \\
\text { lék (9) }\end{array}$} & \multirow[b]{2}{*}{$\begin{array}{c}\text { Limo } \\
\text { nit } \\
(10)\end{array}$} & \multirow[b]{2}{*}{$\begin{array}{l}\text { Nö- } \\
\text { vény } \\
\text { töre- } \\
\text { dék } \\
\text { (11) }\end{array}$} & \multirow[b]{2}{*}{$\begin{array}{l}\mathrm{Ce}- \\
\text { ment } \\
(12)\end{array}$} \\
\hline & $\begin{array}{c}\text { Kvarc } \\
\text { (2) }\end{array}$ & $\begin{array}{c}\text { K- } \\
\text { föld } \\
\text { pát } \\
(3)\end{array}$ & $\begin{array}{l}\text { Plagio- } \\
\text { klász } \\
\text { (4) }\end{array}$ & $\begin{array}{l}\text { Csill } \\
\text { ám } \\
(5)\end{array}$ & $\begin{array}{c}\text { Amfi } \\
\text { bol } \\
(6)\end{array}$ & $\begin{array}{l}\text { Klo- } \\
\text { rit (7) }\end{array}$ & $\begin{array}{l}\text { Járulé- } \\
\text { kos } \\
\text { ásvány } \\
\text {-ok (8) }\end{array}$ & & & & \\
\hline 1 & 92 & 4 & & & $\begin{array}{c}\text { jelen } \\
\text { (a }\end{array}$ & & & 1 & & 3 & jelen \\
\hline 2 & 90 & 5 & 2 & jelen & & jelen & jelen & jelen & & & 3 \\
\hline 3 & 86 & 5 & & 1 & jelen & & jelen & jelen & jelen & 1 & 7 \\
\hline 4 & 80 & 8 & 2 & & 1 & 1 & 1 & 4 & & jelen & 3 \\
\hline 5 & 90 & 4 & & jelen & 1 & & jelen & 2 & jelen & jelen & 3 \\
\hline 6 & 90 & 3 & 1 & 1 & & 1 & & jelen & & & 4 \\
\hline 7 & 83 & 6 & & 1 & jelen & jelen & jelen & jelen & 2 & 2 & 6 \\
\hline 8 & 90 & 4 & jelen & & jelen & & jelen & jelen & jelen & & 6 \\
\hline $\begin{array}{r}\text { Cube } \\
1 \\
\end{array}$ & 88 & 3 & 3 & 1 & & & 1 & 2 & jelen & & 2 \\
\hline $\begin{array}{r}\text { Cube } \\
2 \\
\end{array}$ & 83 & 3 & 2 & jelen & 1 & jelen & 1 & 3 & 2 & 1 & 4 \\
\hline
\end{tabular}

4. táblázat

A minták mikroszkópos vizsgálat alapján becsült ásványi összetétele (\%)

A mintákban, kis mennyiségben (max. 4\%) jelen vannak a különböző kőzettörmelékek: riolit, bontott bázikus vagy intermediert vulkáni kőzet, csillámos kvarcit, mészmárga, aleuritos homokkő és kova szemcsék. Szintén, mint törmelékes ásványi fázis jelennek meg a limonit-pelletek és kéreg-töredékek, a sejtes szerkezetü üde és szenesedett növényi részek is (I. tábla, 4. fotó).

A kovárványlencsék közötti homokszintek nagyrészt kötőanyag-mentesek. Ahol a homok gyengén kötött rögöket képez, az azt jelzi, hogy a szemcsék érintkezési pontjainál megjelenik a meniszkusz-cement. Az összeálló kovárványban a homokszemcsék köztes terét részben vagy teljesen a finom szemü kötőanyag tölti 
ki. Ennek az ásványi összetétele az optikailag is azonosítható kvarcon (max. 57\%) kívül a röntgendiffrakciós vizsgálat által kimutatott agyagásványokból (illit, montmorillonit, klorit), vasásványokból (goethit, hematit) és jelentős mennyiségü röntgenamorf kolloidból áll, amelynek a részaránya a kovárványminták esetében 68\% között van (5. táblázat).

\begin{tabular}{|l|r|r|r|r|r|}
\hline \multicolumn{1}{|c|}{ Minta száma (1) } & \multicolumn{1}{c|}{ 2.(b) } & \multicolumn{1}{c|}{ 7.(d) } & \multicolumn{1}{c|}{ 8.(e) } & \multicolumn{1}{c|}{ Cube 2(f) } \\
\hline Montmorillonit (2) & (a)jelen & 4 & 5 & 2 & 6 \\
\hline Illit (3) & 2 & 6 & 10 & 3 & 10 \\
\hline Illit-montmorillonit (4) & & jelen & 2 & & 2 \\
\hline Klorit (5) jelen & 4 & 3 & jelen & 4 \\
\hline Kvarc (6) & 92 & 62 & 56 & 87 & 57 \\
\hline K-földpát (7) & & 1 & 2 & 3 & 3 \\
\hline Plagioklász (8) & 2 & 4 & 7 & jelen & 4 \\
\hline Goethit (9) & jelen & 6 & 4 & jelen & 2 \\
\hline Hematit (10) & & jelen & & 1 & 4 \\
\hline Gipsz (11) & 4 & 8 & 6 & 3 & 2 \\
\hline Amorf fázis (12) & 100 & 100 & 100 & 100 & 6 \\
\hline Összesen (13) & & & & 100 \\
\hline
\end{tabular}

MÁFI fázisanalitikai labor., Kovács-Pálffy P., Kónya P. (2008-2015)

5. táblázat

A $\emptyset<0,063$ mm-es frakció röntgendiffrakciós analízise (\%)

Az agyagásványok röntgendiffrakciós képe a talajokban gyakori rendezetlen rácsszerkezetre utal: széthúzott vagy hiányzó bázisreflexiók és az illitmontmorillonit szabálytalan kevertszerkezetủ fázis megjelenése (MEHRING, 1975; MELKERUD, 1986). Ugyancsak az illit-montmorillonit páros folyamatos átalakulására utalnak a pásztázó elektronmikroszkópos felvételeken az illit lemezkék peremén látható jégcsap alakú túlnövések.

A finom szemcsés és kolloidális ásványi fázis a pásztázó elektronmikroszkópos felvételeken a szemcseköz alapanyagaként szerepel, a felületi csiszolatokban viszont megjelennek benne a mikronnál kisebb, jó fényvisszaverő tük, szálkák, halmazok (I. tábla, 3. fotó), valószínűleg a ferrihidrites gélből kiváló goethit (SCHWERTMANN és CORNELL, 1986). Ezt az átalakulást egyes szemcsék bevonatában is észleltuik.

A szemcsemorfológia, alak és koptatottság mértékének vizsgálatánál a vizsgálat tárgyát a minták 0,1-0,3 mm-es szemcsefrakciói képezték, amelyen a szemcsék alakját és koptatottságát részben optikai, részben elektronmikroszkópos módszerrel végeztük, ugyanis az ennél kisebb szemcsék rendszerint az aleurit-frakcióhoz hasonlóan élesek-hegyesek, a durvább szemcsék viszont nagyrészt összetett jellegüek (összetapadt halmazok vagy többásványos kőzettörmelékek) ezért nem alkalmasak összehasonlítható eredmények kiértékelésére (MOLNÁR et al., 1989). 
Ezek figyelembe vételével összehasonlítottuk a kovárvány mintákat és a környezetet képező homokminták kvarcszemcséinek az alak-, ill. koptatottság számszerü eloszlását (4. és 5. ábrák).

A szemcsék alakja között szignifikáns a különbség: a kovárványszint szemcséi között jelentősen több a hosszúkás, oszlopos és lapos — és kevesebb az izometrikus szemcsék részaránya, mint a környező homokmintákban (6. táblázat).

\begin{tabular}{|l|r|r|r|r|}
\hline \multirow{2}{*}{ Szemcse-alak (1) } & \multicolumn{2}{|c|}{ Köztes homok } & \multicolumn{2}{|c|}{ Kovárvány } \\
\cline { 2 - 5 } & $\begin{array}{c}\text { Szemcsék száma } \\
(2)\end{array}$ & $\%(3)$ & $\begin{array}{c}\text { Szemcsék száma } \\
\text { (4) }\end{array}$ & \multicolumn{1}{c|}{$\%$} \\
\hline Izometrikus (a) & 185 & 60,06 & 175 & 47,13 \\
\hline Hosszúkás (b) & 84 & 27,27 & 115 & 31,17 \\
\hline Oszlopos (c) & 17 & 5,52 & 36 & 9,76 \\
\hline Lapos (d) & 22 & 7,14 & 43 & 11,65 \\
\hline Összesen (e) & 308 & 100 & 369 & 100 \\
\hline
\end{tabular}

\section{Táblázat}

A köztes homokrétegek és a kovárványrétegek kvarcszemcse alakjainak összehasonlítása

Ugyancsak jelentős különbség mutatható ki a szemcsék koptatottságán: a kovárvány homokszemcséi között jóval több a szegletes, éles élü-hegyes sarkú, mint a köztes homok szemcséi között (7. táblázat), ez arra utal, hogy az ásványi szemcsék korróziója és felaprózódása a gyökérszinten történt a kibocsájtott gyökérsavak és nyomás hatására.

\begin{tabular}{|c|c|c|c|c|}
\hline \multirow{2}{*}{ Koptatottság (1) } & \multicolumn{2}{|l|}{ Köztes homok (2) } & \multicolumn{2}{|l|}{ Kovárvány (3) } \\
\hline & Szemcsék száma (4) & $\%$ & Szemcsék száma (4) & $\%$ \\
\hline Koptatott (a) & 52 & 15,86 & 41 & 8,39 \\
\hline Részben koptatott (b) & 303 & 34,12 & 145 & 29,65 \\
\hline Részben szegletes (c) & 345 & 38,85 & 142 & 29,04 \\
\hline Szegletes (d) & 188 & 11,17 & 161 & 32,92 \\
\hline Összesen (e) & 888 & 100 & 489 & 100 \\
\hline
\end{tabular}

\section{Táblázat}

A köztes homok és a kovárvány homokszemcsék koptatottságának összehasonlítása

A pásztázó elektronmikroszkópos fotókon is észlelhetünk különbségeket a köztes homok- és a kovárvány homokszemcséi között. Így a köztes homokrétegek jól koptatott kvarcszemcséi sima felületüek, amelyeken finom sávok jelzik az eredeti metamorf kvarc belső szerkezetét. Jelen vannak az ütközések során keletkezett, csillagszerü hajszálrepedések, az eolikus szállítás bélyegei. Ugyanakkor láthatók a mikronos nagyságú, lapos vagy rizsszem alakú, részben lekoptatott kovagumók, a folyóvízi szállítás során történt kioldásra-kicsapódásra utaló jelek 
(WALKER és DOUGLAS, 1984). A kovárvány kvarcszemcséi között viszont gyakoriak az erősen korrodált, 1-3 $\mu$ m-es kioldásos barázdákkal tagolt szemcsék, agyagos-limonitos kitöltéssel. A korrózió esetenként oly mértékủ, hogy a szemcse széteséséhez, szilánkokra való feldarabolásához vezet (5. ábra D. fotó; I. tábla, 2. fotó)

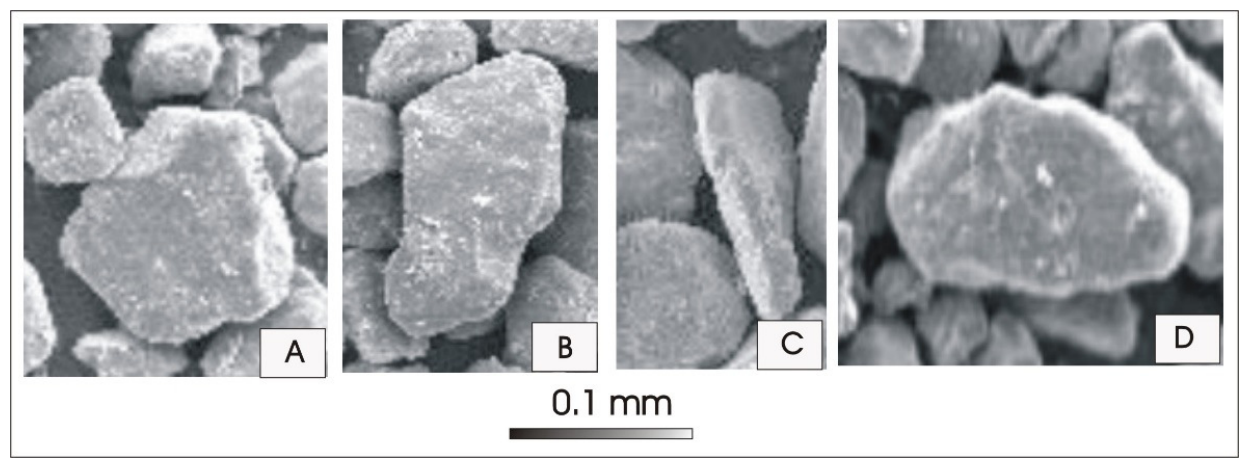

4. ábra

A homokszemcsék alakja A. Izometrikus; B. Hosszúkás; C. Oszlopos; D. Lapos. (SEM fotók)
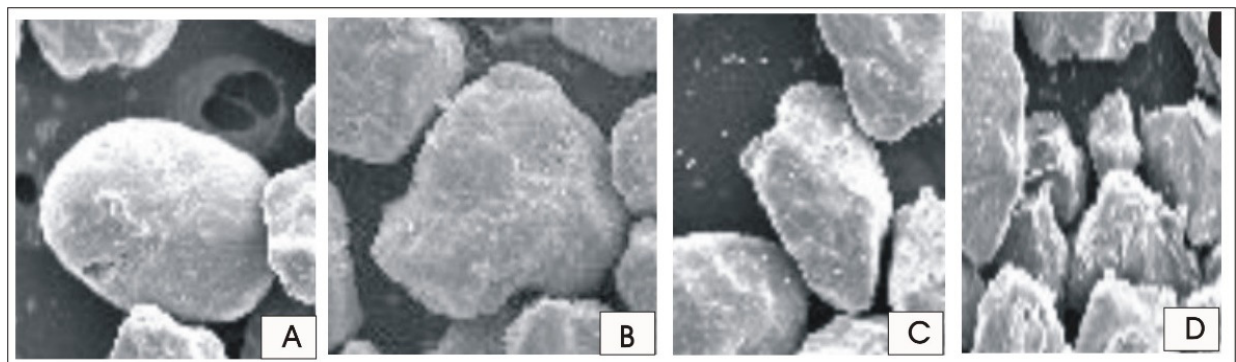

$0.1 \mathrm{~mm}$

5. ábra

Homokszemcsék koptatottsága. A. Koptatott; B. Részben koptatott; C. Részben szegletes; D. Szegletes, szilánkos szemcsék csoportja (SEM fotók)

Míg a környező homok szemcséi nagymértékben fedetlenek, a kovárványban jelen vannak a limonitos-agyagos bevonatok: gyürt, részben levált-leszakadt hártyák vagy burkolatok, száradási repedésekkel. Gyakoriak a részben átkristályosodott limonittal bevont szemcsék is (I. tábla, 6. fotó).

A szemcseméret eloszlás szempontjából a vizsgált minták homok jellegüek, kis mennyiségü agyag- és kőzetliszt frakcióval, amint a talajtani vizsgálatok is kimutatták. A kovárványszintek (3, 5, 7, 3-2, 7,2 és Cube 2 minták) és a köztes homokrétegek közti különbség ezen frakciók részarányában jelenik meg. A 
kovárványban az agyag $(0,002-0,005 \mathrm{~mm}) 7-10 \%$ között és a kőzetliszt $(0,005-$ $0,06 \mathrm{~mm}) 1-6 \%$ között van képviselve, míg a köztes homokrétegek $\emptyset 0,063 \mathrm{~mm}$ alatti frakciója csak $1,0-3,3 \%$ részarányban van jelen.

Ha a kumulatív szemcseösszetétel alapján, a FOLK és WARD (1957) algoritmusát alkalmazva a szemcseeloszlás paramétereit hasonlítjuk össze, észlelhetők a kovárvány- és a köztes homokminták közötti különbségek (KALMÁR et al. 2017).

Ha a fenti paramétereket egymáshoz viszonyítjuk, FRIEDMAN (1971) szerint az adott homok genetikájára vonatkozó információkat kaphatunk. Párosítva a $\mathrm{M}_{\mathrm{z}} / \sigma$, $\mathrm{M}_{\mathrm{z}} / \mathrm{S}_{\mathrm{k}} \mathrm{S}_{\mathrm{k}} / \sigma$ és $\mathrm{S}_{\mathrm{k}} / \mathrm{K}_{\mathrm{G}}$ paramétereket, a kovárvány- és a köztes homok mintái jól elkülönülnek (KALMÁR et al. 2017).

A homokbuckák korántsem homogén szemcsehalmazok; különböző szemcseméret-eloszlású és tömörségủ sávokból, lencsékből és rétegekböl állnak hagymahéjszerü (,onion structure”) szerkezetben (PETTIJOHN et al., 1973)

A feltárás szintjén a vasoxidokban gazdag betelepülések többé-kevésbé szabálytalan, de konkordáns lencséket képeznek a bucka sárgás homokrétegei között. Amint a szemcseméret-eloszlás során kiderült, a kovárványszintek összességükben finomabb szemcsetartományban jelennek meg — és ezt nem csak a kötőanyag nagyobb részaránya, hanem a homokszemcsék felaprózódása okozza (az agyagásvány feldúsulás relatív, vagyis a homok részaránya fogy). Ami a konkordanciát illeti, ez a lencsék felső határán nagymértékben teljesedik. Habár itt is látunk több centiméteres, rücskös felületü tarajokat, vályúkat és üregeket ( $I$. tábla, 5. fotó), az utóbbiakban aránylag durvább homokot, netán egy-egy szem simára legömbölyített gyöngykavicsot. Nem úgy a lencsék és a fekü viszonyában. Itt deciméteres-centiméteres léptékben a kovárványból kúpok, gyökérszerü, néhol kacskaringós benyúlások, láthatók (6. ábra), esetenként folyamatosnak látszó átmenet a vasas és a vasszegény homok között.

A kovárvány és az azt befogadó homok között a szerkezeti-szöveti különbségek a centiméteres-miliméteres léptékben észlelhetök. Az $5 \times 5 \mathrm{~cm}$-es zavartalan monolit-mintákban már kis nagyításnál kiderül, hogy homokszemcsék hosszirányban irányítottak és 5-10 mm-es, színben és szemcseméretben alig láthatóan különböző elemi rétegeket, laminákat képeznek. Ez valójában az eolikus homokformák jellegzetes szövete (FRIEDMAN, 1961). A kovárványban viszont a laminák mindössze néhány milliméteresek, és föleg a limonitos-agyagos mátrixban rajzolódnak ki. Végül mikroszkópos szinten a még meg nem kötött, képlékeny (gélszerü) közegben végbement szemcsemozgások nyomai is követhetők: megbillent szemcsék, behajlított csillám- és kloritlapok és növénytöredékek, egymásba torlódó éles kvarcszemcsék. A lamináris szövetben helyenként folyós szerkezetek, betüremlések és mini-gyưrődések észlelhetők, ami a felette élő növényzet és annak gyökérzete hatására következett be.

Itt kell megemlíteni a kovárványszintekből származó 2-5 cm-es, szegletes, vagy gyengén koptatott töredékeket, amelyek a befogadó homokrétegekben jelennek meg, és magában a kovárványban gyakori 1-5 mm-es sötétbarna, kemény limonitgumókat, amelyek helyenként önálló, szabálytalan lencsékbe tömörülnek a kovárványréteg felső felülete közelében (6. ábra). Gyepvasércekben, többek között 
a dunántúli vaslerakódásokban, limonit lencsékben (FÜGEDI et al, 2004) jelennek meg hasonló képződmények.

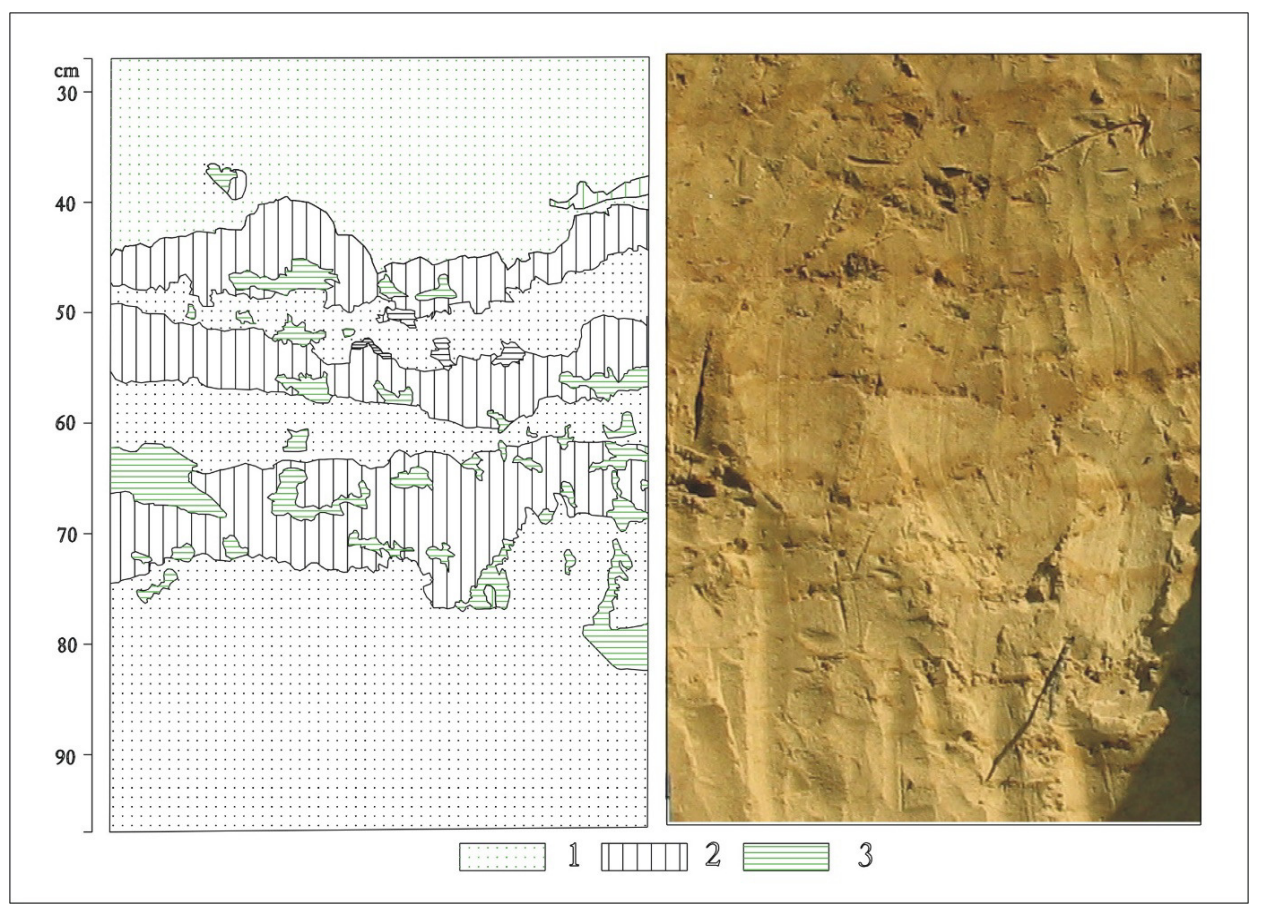

6. ábra

A kovárványszintek a feltárás falán (jobbra) és a zöld fényben szürt kontúr (balra). 1. Laza homok; 2. Kovárvány; 3. Limonit kiválások

\section{A talajkémiai és geokémiai vizsgálatok ásványtani vonatkozásai}

A humusztartalom csak a felszínközeli, 1., 2. és 3. mintákban ér el szignifikáns értékeket. Jelenléte ezek szerint a jelenkori talajképződési folyamatokhoz kötődik.

A pH értékek a felszíni mintákban 6 alatt, a többi mintában 6 felett változnak. Ásványtani szempontból nincs szignifikáns különbség a kovárvány minták és környezetük pH-értékei között.

Míg az oxalátos extrakció csak az amorf vas-oxihidroxidokat addig a ditionos extrakció az ásványosodott vasvegyületeket is oldja, vagyis ha az $\mathrm{Fe}_{\mathrm{ox}} / \mathrm{Fe}_{\mathrm{dit}}$ kisebb, mint 1, akkor a vasvegyületek jobban kristályosodottak (BOHL et al., 1985). Ezek ismeretében a $\mathrm{Fe}_{\mathrm{ox}} / \mathrm{Fe}_{\text {dit }}$ hányados a vasásványok kristályosodási fokát, tehát az ásványi közeg földtani értelemben vett érettségét illusztrálja (NEMECZ et al., 1995) és azt bizonyítja, hogy a szelvény zavaratlan, normális üledék-felhalmozódást tárt fel, amelyben a vasas szintek jelentős mennyiségủ vasvegyületet, köztük kolloidális vastartalmat konzerváltak Ezt a röntgendiffrakciós vizsgálat is szemlélteti. 


\begin{tabular}{|l|r|r|r|r|r|r|r|}
\hline \multirow{2}{*}{ Elemek, ppm (1) } & \multicolumn{7}{|c|}{ Minták } \\
\cline { 2 - 8 } & $3 .(2)$ & $4 .(3)$ & $5 .(4)$ & $7 .(5)$ & $9 .(6)$ & Cube 1 (7) & Cube 2 (8) \\
\hline $\mathrm{As}$ & 12 & $<5$ & 10 & 8 & 15 & 6 & $<5$ \\
\hline $\mathrm{Ba}$ & 77 & 12 & 65 & 56 & 46 & 15 & 22 \\
\hline $\mathrm{Ca}$ & 755 & 320 & 860 & 1220 & 1550 & 745 & 720 \\
\hline $\mathrm{Co}$ & 15 & $<1$ & 7 & 12 & 15 & 8 & 5 \\
\hline $\mathrm{Cr}$ & 105 & 5 & 65 & 72 & 38 & 42 & 37 \\
\hline $\mathrm{Cu}$ & 25 & $<1$ & 17 & 10 & 8 & 22 & 15 \\
\hline $\mathrm{Fe}$ & 2550 & 755 & 2870 & 2050 & 1120 & 1405 & 1355 \\
\hline $\mathrm{K}$ & 1765 & 615 & 1850 & 1655 & 1523 & 1020 & 960 \\
\hline $\mathrm{Mg}$ & 470 & 150 & 550 & 825 & 1050 & 660 & 513 \\
\hline $\mathrm{Mn}$ & 285 & 15 & 300 & 156 & 278 & 305 & 270 \\
\hline $\mathrm{Na}$ & 550 & 155 & 420 & 510 & 565 & 532 & 478 \\
\hline $\mathrm{Ni}$ & 17 & $<5$ & 66 & 28 & 38 & 22 & 32 \\
\hline $\mathrm{P}$ & 455 & 105 & 332 & 270 & 178 & 205 & 300 \\
\hline $\mathrm{Pb}$ & 10 & $<5$ & 15 & 32 & 22 & 18 & 24 \\
\hline $\mathrm{Sr}$ & 178 & 52 & 211 & 220 & 305 & 142 & 105 \\
\hline $\mathrm{Ti}$ & 155 & 25 & 150 & 175 & 145 & 38 & 105 \\
\hline $\mathrm{V}$ & 106 & 35 & 316 & 203 & 155 & 105 & 98 \\
\hline $\mathrm{Zn}$ & 216 & 18 & 185 & 175 & 108 & 96 & 45 \\
\hline
\end{tabular}

\section{8. táblázat}

Táp- és nyomelemek (mg/kg-ban) a 3., 5., 7. és 8. kovárványmintákban, a 4. homokmintában és a monolitok anyagában.

A 8. táblázatban a 32 elem közül a geokémiai szempontból szignifikáns elemek koncentrációját mutatjuk be.

Első ránézésre a királyvizes kioldású, gyakorlatilag a teljes vastartalom jelentősen magasabb, mint az oxalátos, vagy a ditionitos extrahálás értéke, ugyanis ebben a roncsolásban a törmelékes vasásványok és szilikátok (klorit, biotit, amfibol, ill. kőzettörmelékek) vastartalma és implicite, a nyomelemei is kimutathatók. Így megjelennek és a vastartalommal korrelálhatók az As, $\mathrm{Cr}, \mathrm{Co}, \mathrm{Mn}, \mathrm{Ni}, \mathrm{Mn}$ és $\mathrm{Zn}$ nyomelemek, amelyek komplexeket képeznek nem csak a limonit-gélben, de a szerves anyagban is (SCHWERTMANN et al., 1968).

Habár a karbonát-koncentráció a mintákban nem kimutatható, jelentős, esetenként az 1000 ppm-et meghaladó a minták Ca- és Mg-tartalma. Ez valószínủleg adszorbciósan kötött fázis, és a lebomló (lebomlott) növényi anyaghoz köthető.

Fontos még jelezni a kálium meglehetösen magas koncentrációját, valamint a foszforét és a stronciumét, mint biogén elemek jelenlétét.

Megjegyzendö, hogy a 3., 5., 7. és 9. kovárványmintákban, valamint a monolitok anyagában jelentősen magasabbak a mért nyomelem-koncentrációk, mint a 4. sz. kvarchomok mintában. 


\section{Következtetések}

A kovárványcsíkok kialakulása egyes elméletek szerint szoros kapcsolatban van a talaj szemcseösszetételével. STEFANOVITS elmélete szerint kovárványosodás olyan homokban képződik, amelynek 10\%-nál kevesebb a leiszapolható rész tartalma és $5 \%$-nál kisebb az agyagos rész tartalma (STEFANOVITS et al., 1999). A 2. táblázatban látható, hogy a nem kovárványos mintákban $10 \%$ alatt marad a leiszapolható rész aránya, kivéve a 4 és 13 -as mintát, 12,2\%-al, illetve 12,5\%-al. Itt kell megjegyezni, hogy a nagyon vékony és laza rétegekből nehéz a pontos talajminta begyüjtése! Tehát adottak volnának a szelvényben a kovárvány képződés STEFANOVITS által meghatározott feltételei.

Ezek ismeretében a tamáspusztai feltárásban az itt megjelenő kovárványszinteken és a köztes, ill. az alatta lévő homokrétegeken talajtani, mikrobiológiai és ásványtani vizsgálatokat végeztünk. Az eredmények alapján meglehetősen pontos válaszokat adhatunk a bevezetőben feltett kérdésekre.

1. A homokdombok (dủnék) folyóvízi eredetủ homokból, a pleisztocénben (és a holocén száraz időszakaiban) alakultak ki, ill. vették fel jelenlegi alakzatukat a szél hatására. Kialakulásuk után a vízerózió hatása nem volt jelentős. A szemcsék felületének vizsgálata kimutatta, hogy a szélerózió által okozott koptatás felülírja a folyóvízi bélyegeket.

2. A kovárványos és a nem kovárványos rétegek homokfrakciója mindenben azonos ásványi összetételü, és ugyanazon homoktest része. Különbségek a homokszemcsék felaprózódásában, a szemcseméret csökkenésében és föleg a kötőanyag jelenlétében, ill. az uralkodóan limonitos összetételében van. Fontos megállapítani, hogy az átlagos szemcseméret-csökkenést a kovárványképződéssel együtt járó biológiai eredetủ korrózió és feldarabolás is okozta.

3. A kovárvány kötőanyagát képező vashidroxidok és agyagásványok - a kovárványlencsék alakzata alapján látható, hogy centiméteres-deciméteres mértékben behatoltak, beszivárogtak az alattuk lévő homokba. Ugyanakkor a kovárvány felső felülete éles, helyenként bekérgeződött, széleróziós nyomokkal.

4. A talajvíz hatása a kovárványos vasfelhalmozódásra kizárható, mivel jelenleg a talajvízszint 8-10 m mélységben van, és még a legcsapadékosabb időszakban sem lehetett magasabb, mint a buckaközi laposok szintje. Ez utóbbi megfelel a fúrásban leírt glejesedés szintjével (kb. 4 m-re a bucka teteje alatt).

5. A kovárványos vasfelhalmozódás felszínközeli, azaz talajtani folyamatokra vezethető vissza és ezt a talajtani, mikrobiológiai és ásványtani vizsgálatok egyértelmủen alátámasztják.

Szemcseszinten a kovárványmintákban tetten érhető a kvarc- és egyéb szemcsék korróziója, feldarabolása, amely a folyóvízi és eolikus szállítás bélyegeit felülírja. Hasonló biológiai eredetủ feldarabolás a növényzet $\mathrm{SiO}_{2}$-ellátásával függ össze (WILDING et al., 1977) és jelenleg is folyamatban van az erdős területek talajában és a képződő gyökérsavak hatásának eredménye.

A kovárvány megkötését (részleges litifikációját) megelőzően szemcse- és kötőanyag szintủ mozgás bélyegei láthatók, amire az önsúly alatti tömörülés önmagában nem ad magyarázatot. A talajtani vizsgálatok paraméterei, és a 
mélységgel csökkenö, de minden szintben nyomon követhető mikrobiológiai aktivitás is erre utalnak.

A tamáspusztai feltárás kovárványszintjei tehát részben széleróziót szenvedett, betemetett talajszintek, amelyeknek talajtani besorolása kovárványos barna erdőtalaj volt, most pedig a WRB osztályozás szerint Lamellic Arenosol.

Nemcsak Magyarországon, de számos területen, ahol időnként mozgó, időnként megkötődő homokformák vannak, megjelennek a betemetett talajszintek. A távoli korok litifikált talajszintjein kívül csak egy példa: a nyírségi dűnékkel egyidős Halloch-Latenbdorf terület (Schleswig-Holstein), ahol egy würm/holocén (Bölling) és két holocén korú podzolos talajszint jelenik meg a moréna eredetü homokdűnében (GRUBE, 2016).

E talajszintek keletkezésének alapvető feltétele a buckákat (legalább részben) lefedő jelentős szerves anyagot termelő vegetáció. A kovárványszintek vashidroxidja szerkezetileg és geokémiailag is biológiai eredetủ, akárcsak a napjainkban is keletkező gyepvasérc anyaga (BORCKERT, 1960).

A BORSY (1961) által feltételezett fenyő-nyír-kor III vagy IV fázisában és a holocén hasonló, csapadékosabb időszakában keletkezhettek a vizsgált vasoxihidroxid tartalmú rétegek, de nem a pH-szabályozott vasszivárgásból, hanem magában a lebontott, megfelelő mennyiségü szerves anyagból. A vasat (és a vassal együtt járó nyomelemeket) a növényzet a homok vastartalmú ásványaiból kivonta, szervezetében „koncentrálta” és így jutott vissza a talajba.

Ha körülnézünk a Nyírségben, de a Duna-Tisza közén és Dél-Dunántúlon is, az utóbbi 20-30 aránylag csapadékosabb (és melegebb) évek során mindenütt vegetációval fedett, esetenként erdővel benőtt vagy beültetett buckákkal találkozunk. Így az 1996-ban még aktív homokbányákat, mint pl. a Rém vagy Borota közelében levőket jelenleg befedte a növényzet (KUTI et al., 2001). A tamáspusztai szelvény 5-25 cm-es szintje analitikailag nagyon közel áll a kovárványhoz; ezért itt minden bizonnyal egy leendő kovárványszint keletkezését érjük tetten.

\section{Összefoglalás}

A Nyírség egyik jellegzetes talajtípusa a kovárványos barna erdőtalaj. Mind hazánkban, mind külföldön sokan vizsgálták a kovárványképződést és állítottak fel természettudományosan megalapozott elméleteket a képződés mikéntjére vonatkozóan. Leggyakrabban a vas-vegyületek lefelé irányuló mozgásávbal és adott mélységben történő kicsapódásával próbálták meg leírni a jelenséget. Munkánk célja ásványtani, talajtani és mikrobiológiai vizsgálatok segítségével megválaszolni a kovárványképződésének kérdését.

A Nyírség tamáspusztai homokdomb alapvetően homogénnek tekinthet ásványi összetételét tekintve. A kovárványszintek képződésének korábban leírt kémiai és szemcseösszetételbeli kritériumai teljesülnek (pH 4.5-6.5 közé esik, a szemcseösszetétel pedig a kovárványrétegben meghaladja a leiszapolható rész 10 $\%$-ot). Részletesen vizsgálva a kovárványrétegeket benne a homokszemcsék korrodáltak, töredezettebbek, ami mind egykori gyökérnedvek korróziójának 
eredménye lehet. A homokszemcsék kötőanyaga a kovárványrétegben elsősorban vas-oxihidroxidból áll, és a kovárványréteg eredetileg képlékeny, gyúrt, szakadozott szerkezetet mutat. A kovárványréteg felső része erodált, ami egykori talajfelszínen történő elhelyezkedését jelzi. A réteg alsó része tagolt és gyakran benyúlik az alatta elhelyezkedő homoktestbe. Véleményünk szerint a vas-oxihidroxid kiválások a kovárványrétegben alapvetően biológiai (növényi vas felvétel, majd elhalás után mikrobiális bontás segítségével létrejött vas-oxihidroxid akkumuláció) akkumulációs és kiválási folyamatokra utalnak. Mindezek alapján úgy gondoljuk, hogy a kovárványrétegek az egykori homokdomb felszínén képződtek és nem később bekövetkezett vasmozgás során jöttek létre.

Kulcsszavak: Nyírség, Kovárvány, Talajásványok, Fe-eloszlás, Mikrobiológiai vizsgálatok 


\section{Tábla}
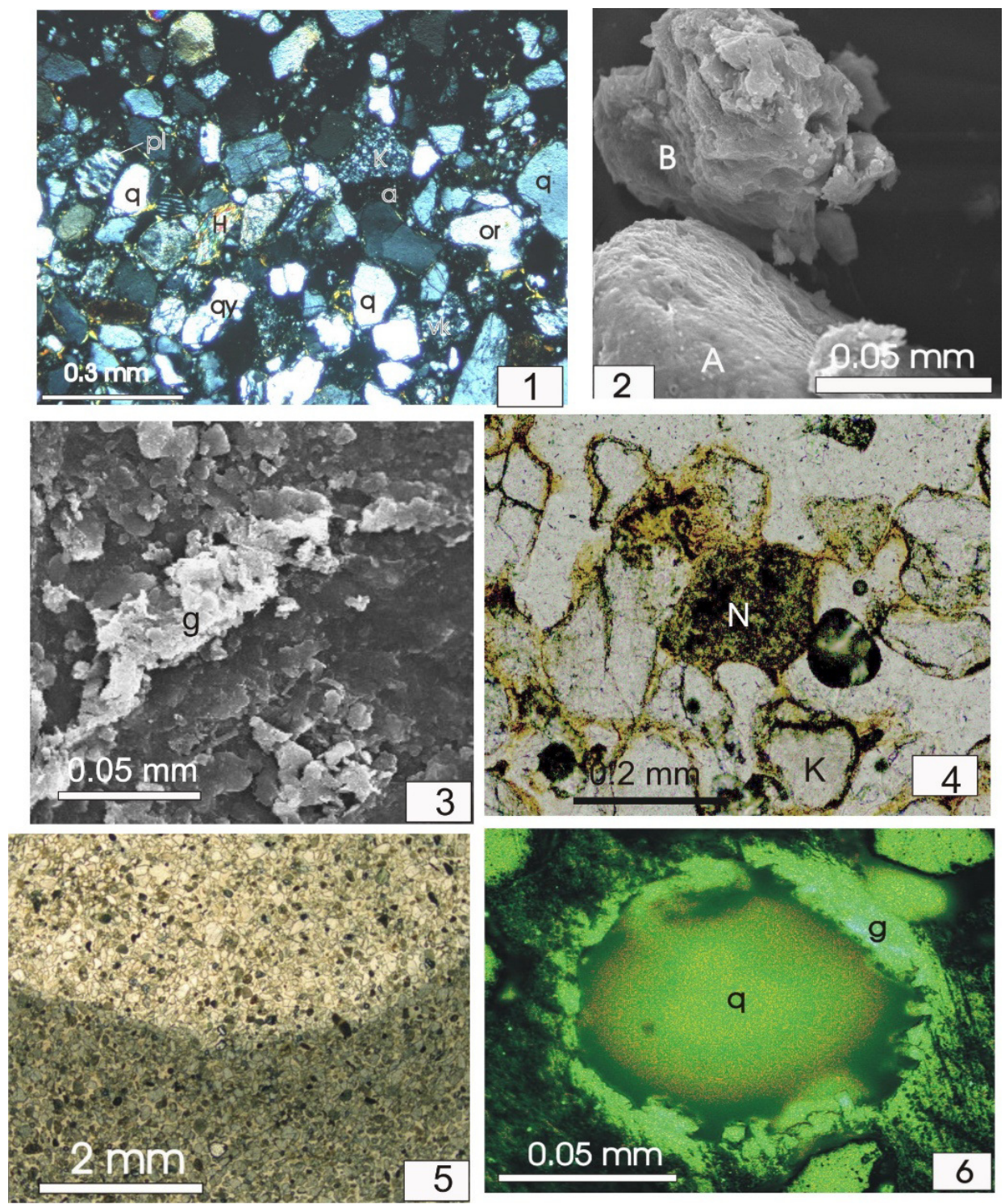

1. Fotó. Enyhén irányított kovárvány vékony csiszolatban. q, kvarc; qv, felrepedezett, korrodált kvarcszemcse; or, ortoklász; pl, plagioklász; h. hornblende; v, bontott vulkáni kőzet; a, izotróp agyagos-limonitos alapanyag. 3. kovárványszint, + nikolok. Photo 1. Thin section of slightly oriented iron rich sand . q, quartz,; qv, crushed, corroded quartz grain; or, orthoclase; pl. plagioclase; h, hornblende; v, wheatered volcanic rock grain; $\mathrm{a}$, isotrope clayey-limonitic matrix. Third iron rich sand level; crossed nichols. 
2. Fotó. Gömbölyü, simára koptatott (A) és erősen korrodált kvarcszemcse (B). 5. kovárványszint, SEM fotó. Photo 2. Rounded and smooth (A) and hardly corroded (B) quartz grains. $5^{\text {th }}$ iron rich sand level, SEM photo.

3. Fotó. Goethit-hasábok halmaza (g) a 3. kovárványszintből. SEM fotó. Photo 3. Goethite prism aggregate (g)from the third iron rich sand level, SEM photo.

4. Fotó. Részben bontott, sejtes szövetü növénytöredék (N) és limonittal burkolt káliföldpát-szemcse (K) a 3. kovárványszintből. Vékony csiszolat, II nikolok.Phpto 4. Partly decomposed plant fragment with cellular structure $(\mathrm{K})$ from the third iron rich sand level. Thin section, II nichols.

5. Fotó. Az 5. kovárványszint felső felületé, egy vályúszerü bemélyedéssel. Cube-1 minta, vékony csiszolat, II nikolok. Photo 5. Tought like cove ont he upper surface of the iron rich sand level. Undisturbed sand sample Cube 1, thin section, II nichols.

6. Fotó. Korrodált kvarcszemcse $(\mathrm{q})$, goethit burokkal $(\mathrm{g})$. 7. kovárványszint, felületi csiszolat, kék szürővel. Photo 6 . Corroded quartz grain $(\mathrm{q})$ with goethite coating $(\mathrm{g}) .7^{\text {th }}$ iron rich sand level, polished section, with blue light filtre.

\section{Irodalom}

BERG, R.C. 1984: The origin of the early genesis of clay bands in youngful sandy soils along lake Michigan, USA. Geoderma, 32., 45-62.

BoHL, H., MCClean, B., O'ConNOR, G. 1985: Soil chemistry. Chapter 3.5.3. Iron minerals - Mezőgazdasági Kiadó és Gondolat Kiadó, 112-113. Budapest..

BORCKERT, H. 1960: Genesis of sedimentary iron ores. — Trans. Inst. Min. Metall. 69., 161-179; 530-539. London

BoRsY Z. 1961: A Nyírség természeti földrajza. - Akadémiai Kiadó, Budapest, $227 \mathrm{p}$.

BulgăREANU, C. 1968: Nisipurile eoliene din Câmpia de Vest. — St. Cerc. Geol., Geogr. Geof., seria Geol., XXXVIII., 26-45. Bucureşti

BURÓ B., 2015: Recens és szubrecens felszínformáló folyamatok vizsgálata a nyírségi homokterületen. - $\mathrm{PhD}$ Értekezés, Debreceni Egyetem Földtudományi Doktori Iskola, 150. p.

BUZÁs I. (szerk.), 1988: Talaj- és agrokémia vizsgálati módszerkönyv 2. A talajok fizikai-kémiai és kémiai vizsgálati módszerei. Mezőgazdasági Könyvkiadó Vállalat. p. 227., Budapest.

CORNELL. R.M.. 1986: The effect of silicate on the transformation of ferryhidrite into goethite and/or hematite. $-13^{\text {th }}$ Congress International of Society of Soil Scientists, Abstr., p. 1441, Hamburg,.

DöVÉNYI Z. (szerk.) 2010: Magyarország kistájainak katasztere. Második, átdolgozott és bővített kiadás, Magyar Tudományos Akadémia, Budapest, p. 876.

DiJkerman, C., Cline, M.G., OLSON, G.V. 1967: Properties and genesis of textural subsoil lamellae. Soil Science 104., 7-16.

DumitRAşCU, S. 1974: Repertoriul monumentelor din jud. Sălaj şi Bihor. Muzeul Judeţean Bihor, 51., 1074-1078, Oradea -Nagyvárad 
FIGLER R.: (2010) Kovárványrétegek vizsgálata a nyírségi Tamáspuszta egyik homokdombján, Diplomadolgozat SZIE Gödöllő.

FOLK, R.L., WARD, W.C. 1957: Brazos River Bar: A study in the significance of grain size parameters. - J..Sed. Petr., 27., 3-27.

FRIEDMAN, G.M. 1971: Distinction between dune, beach and river sands from their textural characteristics. J.. Sed. Petr., 31., 4., 514-529.

Fügedi U., Kuti L., Kalmár J., Müller T., Szenderiné Koren E. 2007: A Pornóapáti-Dozmat felszínközeli üledékeinek geológiai-geokémiai vizsgálata. — Földtani Közlöny, 137/1., 369-386. Budapest

GruBE, A. 2016: Das Binnendünnengebiet Halloh-Latendorf (Südlich Boostendlmittlerns Schleswig-Holstein) - Interglaziale und Stadiale Ablagerungen sowie oberholozäne Dünendinamik. — Zeitschrift für Deutsche Geselschaft für Geowisswnschaften. 167. (1), 33-47. Stuttgart

HORVÁTH I., 1985: A kovárványrétegek kialakulása és gazdsági jelentősége. Kossuth Lajos T/udományegetem, Debrecen, szakdolgozat

Ilyushev, D,A., Muratov, G.A., Suleymanova, Sh.E. 2012: Reddish siltic imbeddings in sand dunes of Volga Delta, Astrakhan region, as indicators of level and salinity oscillation of Caspic Sea - Prirodonauchniy Zbornik Volgogradskoy Sektziyi Nauchnovo Akademyi FRR, Volgograd, XXXI., 136148. .

JANKOVSKI, M. 2002: Late periglglacialsoil paleocatena in inland dune area of the Torun Basin, Northern Poland. - Quaternary International, 269.,116-125.

Johnson, D.L., Johnson, D.N., Benn, D.W., BetTis, E.A. 2008: Deciphering complex soil/site formation in sands. - Geomorphology, 101., 484-496.

KÁDÁR L. 1951: A kovárvány-probléma. — Földrajzi Értesítő, XXI., 17-25, Budapest

KALMÁR J., VATAI J. 1994: A Fülöp-Nyírlugos agrogeológiai mintaterület homokos üledékeinek morfológiája. - Debreceni Környezeti Napok, Abstr. 22-24., Debrecen

KAlMÁR J., FÜlEKY GY., KÁTAI J., KUTI L. 2017: Iron rich imbeddings in East Hungarian eolian sand accumulation, Tamáspuszta area: genetic and environmental considerations. Carpathian Journal of Earth and Environmental Sciences, 12., 1, 109-120., Baia Mare

KEMP., R.A.., MCINTOSH, R.P., 1989: Genesis of texturaly banded soil in Southern New Sealand . - Geoderma, 45., 65-81.

KerÉK B., KUTI L., VATAI J. 2001: Az Északkelet-Alföld felszíni-felszínközeli képződményeinek és a bennük mozgó talajvíznek az agrogeológiaikörnyezetföldtani jellemzése. - Acta Geographica, Geologica et Meteorologica Debrecina, Tom. XXXV., 103-116. Debrecen

Kilibarda, Z., Angyilan, E., Blockland, J. 2008: Wind deposition of mud aggregates and thrirrole in development of lamellae im the Fair Oaks Dunes, Indiana. - Catena, 72., 235-247

KINSLEY, D.H., DORNKAMP, J.C. 1973: Atlas of quartz sand surface textures. Cambridge University Press, 91 p., London 
KLITZSCH E, HARns JG, LEJAL-NICOL A, LIST FK 1979: Major subdivision and depositional environments of the Nubian strata, southwest Egypt. Bull Am Assoc Petrol Geol 63., 967-974.

KRIVÁN P. 1958: Jéglencsés-leveles állótundra jelenségek Magyarországon. Földtani Közlemények. 88/2., 201-209.

KUTI L., ZENTAY T., KERÉK B. 2001: A Bugaci- és Fülöpi-mintaterület felszínközeli üledékeinek kalcium-karbonáttartalma - MÁFI Évi jelentés az 1997-1998. évekről, 107-117. Budapest

LOVÁsz Gy. 1997: Magyarország természeti földrajza II. — University Press Pécs Kiadó181 p, Pécs

MAROSI S, 1966: Kovárványrétegek és periglaciális jelenségek összefüggésenek kérdései a felsősomogyi futóhomokban. - Földrajzi Értesítő, XV/I., 27-44.

MeHRING, J. 1975: Smectites. - IN: GIESEKING, J.E. (ed.): Soil components. II. Inorganic components. 7-119. Springer, Berlin, New York.

MELKERUD, P.A. 1986: Clay mineralogical comparisons of weathering profiles associated with spruce and birch stand. - Geol. Fören. Förhanding. 107. 301307 Stockholm

MolnÁR B. 1981: Szedimentológia. I. - József Attila Tudományegyetem, Természettudományi Kar, Földtani és Öslénytani Tanszék, 10-48. Szeged.

Molnár B., FÉNYes J., KuTi L, NovoszÁth L. 1989: A hagyományos és a pásztázó elektronmikroszkópos szemcsealaktani vizsgálati módszerek eredményeinek összehasonlítása. — Földt. Közl. 118. 1. 27-48. Budapest

NEMECZ E., CsIKÓs-HARTYÁNI Zs. 1995: Processes in soils and palaeosoils: a new method for the study of weathering. - GeoJournal, 36., 130-142.

Prusinkiewicz, Z., BednareK, R., Kosko, A., SzMYTM., 1998: Paleopdological studies of the age and properties of illuvia bands in Tan arhaeological site .Quaternary International.,. 51-52., 195-201.

Pettijohn, F.J., PotTer, P.E., Siever, R. 1973: Sand and Sandstone.- 133-135. Springer, New York, Heidelberg., Berlin,

SCHAETZL.,R.J. 2001: Morphological evidence of lamellae formong directly from thin clay beddingplanes in dune. - Geoderma, 79., 51-53.

SChWERTMANN, U., CORNEL, R.M. 2000: Iron Oxides in Field and in the Laboratory. Preparation and characterisation. II ${ }^{\text {d. }}$ ed. 67-91.- Wiley VHC., Weinheim, New York, Brisbaine, Singapore, Toronto

SCHWERTMANN, U., FISCHER, W.R., PAPENDORF, H. 1968: The influence of organic compounds on the formation of iron oxydes. $-9^{\text {th }}$ Congr Intern of Society of Soil Scientists, , I., 645-655 Adelaide.

SOMOGYI S., MAROSI S. 1990: Magyarország kistájainak katasztere I. 479 p MTA Földrajztudományi Kutató Intézet, Budapest

STEFANOVITS P. 1953: A nyírségi kovárvános homok. - A MTA Agrártudományi Osztály Közleményei. III., 1-4., 1-11.

STEFANOVITS P.1963: Magyarország tájainak talajviszonyai. 106 p — Szent István Egyetem, Gödöllő

StefanOvits P. FILEP GY. FÜLEKY GY. 1999: Talajtan.- Mezőgazda Kiadó, Budapest, $470 \mathrm{p}$. 
SZEGI, J. 1979: Talajmikrobiológiai vizsgálati módszerek. 250-256.. — Mezőgazda Kiadó, Budapest

Torrent, J., Nettleton, W,D., Borst, G. 1980: Clay illuvial and lamellae formation in psammitic Haploxeralf in Southern California. Soil Science Society of America Journal, 44., 363-368.

VANCE, E.D., BROOKES, P.C., JENKINSON, D.S. 1987: An extraction method for measuring soil microbial biomass-C. - Soil Biol. Biochem., 19. 703-707.

WalkeR, R. G., Douglas J. 1984: Sandy Fluvial Systems. - In: Walker, R. G. (ed..): Facies models. II ${ }^{\mathrm{d}}$ ed. 71-92. - Geosciences, Toronto.

WILDING, L.P., SMECK, N.E., DREES, L.R. 1977: Silica in soils: quartz, cristobalite, trydimite and opal. - In: Dixon, J.B., Weed, S.B. (eds): Minerals in soil environments. Soil Sci. Soc. Am. Inc., Madison, 471-532.

\title{
Formation of iron-rich layers in sandy soils in the Nyírség region of Hungary
}

\author{
${ }^{1}$ J. Kalmár, ${ }^{1}$ L. Kuti, ${ }^{2}$ J. Kátai, ${ }^{3}$ R. Figler and G. ${ }^{3}$ Füleky \\ ${ }^{1}$ Department of Environmental Geology, Hungarian Institute of Geology and \\ Geophysics, Budapest \\ ${ }^{2}$ Institute of Agricultural Chemistry and Soil Science, Faculty of Food Science \\ and Environment Management, University of Debrecen, Debrecen \\ ${ }^{3}$ Institute of Environmental Science, Faculty of Agricultural and \\ Environmental Sciences, Szent István University, Gödöllö
}

\section{Summary}

One of the most characteristic soils in the Nyírség region of Hungary is brown forest soil with thin layers of iron-rich sand. The formation of these layers has been intensively studied both in Hungary and elsewhere, and various scientific theories have been proposed to explain how they come about. In most cases the downward movement of iron compounds and their precipitation at a given depth have been thought to be responsible for this phenomenon. The aim of the present work was to solve the problem by means of mineralogical, soil science and microbiological analysis.

The Tamáspuszta sand dune in the Nyírség region can be regarded as homogeneous in terms of its mineral composition. The chemical and grain composition criteria previously described for the formation of these layers $(\mathrm{pH} 4.5-$ 6.5 , grain composition with $>10 \%$ silt in the iron-rich layer) are fulfilled. A detailed analysis of the layer showed that the sand particles were corroded and fairly fragmented, which could be the result of earlier corrosion by root sap. In the ironrich layer the sand grains are primarily cemented by iron oxyhydroxide, and the layer exhibits an originally plastic, moulded, fragmented structure. The upper part of the layer is eroded, suggesting that it was once located on the soil surface, while the lower part is cloddy and often reaches into the sandy layer below it. In the 
opinion of the authors, the iron oxyhydroxide precipitation can be attributed primarily to biological (plant iron uptake, followed by iron oxyhydroxide accumulation due to the microbial decomposition of dead plant parts), accumulation and precipitation processes. It is thus thought that these layers were formed on what was once the soil surface, rather than as the result of later iron migration.

Key words: Nyírség region (Hungary), thin iron-rich sand layers, soil minerals, Fe distribution, microbiological analysis

Table 1. Location, type and diagnostic horizon of soil samples from Tamáspuszta. (1) Sample number. (2) Location. (3) Depth, cm. (4) Description of the sample. a) Exterior wall; b) Drilled core; c) Surface; d) Moist sand; e) Sand between the uppermost streak of iron-rich sand and the first layer; f) First iron-rich sand layer; g) Sand between two iron-rich sand layers; h) Second iron-rich sand layer; i) Sand below the second iron-rich sand layer; j) Third iron-rich sand layer; k) Sand below the third iron-rich sand layer; 1) Rusty sand; m) Grey sand; n) Sand between two iron-rich sand layers; o) Iron-rich sand layer.

Table 2. Depth distribution of the $\mathrm{pH}$, humus and Fe content and mechanical composition of samples taken from the wall of the soil profile and from its surface. (1) Sample number. (2) Depth, cm. (3) Upper level of plasticity according to Arany. (4) $\mathrm{pH}_{\mathrm{H} 2 \mathrm{O}}$. (5) $\mathrm{pH}_{\mathrm{KCl}}$. (6) Humus \%. (7) Mechanical composition: Sand \%. (8) Silt $\%$. (9) Clay \%. (10) Oxalate-soluble Fe. (11) Dithionite-soluble Fe. (12) Oxalate/dithionite-soluble Fe.

Table 3. Microorganism population in the soil profile and its microbiological activity. (1) Sample number. (2) Depth, cm. (3) Total microbial count, $10^{6} / \mathrm{g}$ soil. (4) Number of micromycetes, $10^{3} / \mathrm{g}$ soil. (5) $\mathrm{CO}_{2}$ production, $\mathrm{mg} / 100 \mathrm{~g}$ soil/10 days. (6) Microbial biomass, $\mathrm{C} \mu \mathrm{g} / \mathrm{g}$ soil.

Table 4. Mineral composition of the samples estimated by microscopic analysis (\%). (1) Sample number. (2) Minerals: Quartz. (3) K-feldspar. (4) Plagioclase. (5) Mica. (6) Amphibol. (7) Chlorite. (8) Accessory minerals. (9) Rock fragments. (10) Limonite. (11) Plant debris. (12) Cement. a) Present.

Table 5. X-ray diffraction analysis of the $\varnothing<0.063 \mathrm{~mm}$ grain size fraction (\%). (1) Sample number. (2) Montmorillonite. (3) Illite. (4) Illite-montmorillonite. (5) Chlorite. (6) Quartz. (7) Potassium feldspar. (8) Plagioclase. (9) Goethite. (10) Hematite. (11) Gypsum. (12) Amorphous phase. (13) Total. a) Present. (b-f) Samples.

Table 6. Comparison of the shape of quartz sand grains from the host sand and from iron-rich sand levels. (1) Grain shape. (2) Host sand. (3) Iron-rich sand. (4) Number of grains. a) Isometric; b) Elongated; c) Columnar; d) Platy; e) Total.

Table 7. Comparison of the degree of abrasion of sand grains from the host sand and from iron-rich sand levels. (1) Degree of abrasion. (2) Host sand. (3) Ironrich sand. (4) Number of grains. a) Abraded; b) Partially abraded; c) Subangular; d) Angular; e) Total.

Table 8. Nutrients and trace elements $(\mathrm{mg} / \mathrm{kg})$ in iron-rich sand samples Nos. 3, 5, 7 and 9 and in host sand sample No. 4. (1) Elements. (2-8) Samples. 
Figure 1. Location of the outcrops.

Figure 2. The excavated surface at a depth of $\sim 50 \mathrm{~cm}$.

Figure 3. The outcrop.

Figure 4. Shape of the sand grains. A. Isometric. B. Elongated. C. Columnar. D. Platy. (SEM photos)

Figure 5. Degree of abrasion of the sand grains. A. Abraded. B. Partially abraded. C. Subangular. D. Angular, splinty grains. (SEM photos)

Figure 6. Iron-rich sand layers on the wall of the outcrop (right) and their contour in green light (left). (1) Soft sand. (2) Iron-rich sand. (3) Limonite precipitations.

Photo 1. Thin section of slightly oriented iron-rich sand from the $3^{\text {rd }}$ iron-rich sand level. q: quartz; qv: crushed, corroded quartz grain; or: orthoclase; pl: plagioclase; h: hornblende; v: weathered volcanic rock grain; a: isotropic clayeylimonitic matrix. (Crossed nicols)

Photo 2. Quartz grain, round and smooth due to abrasion (A) and severely corroded quartz grain (B) from the $5^{\text {th }}$ iron-rich sand level. (SEM photo)

Photo 3. Goethite prism aggregate $(\mathrm{g})$ from the $3^{\text {rd }}$ iron-rich sand level. (SEM photo)

Photo 4. Partially decomposed plant fragment with cellular structure (N) and potassium feldspar grain coated with limonite $(\mathrm{K})$ from the $3^{\text {rd }}$ iron-rich sand level. (Thin section, II nicols)

Photo 5. Trough-like depression on the upper surface of the $5^{\text {th }}$ iron-rich sand level. Undisturbed sand sample Cube 1. (Thin section, II nicols)

Photo 6. Corroded quartz grain $(\mathrm{q})$ coated with goethite $(\mathrm{g})$ from the $7^{\text {th }}$ ironrich sand level. (Polished section with blue light filter)

\section{A szerzők és bírálóik véleménye a témával kapcsolatban több ponton eltér egymástól, ezért a folyóirat további vitának helyet ad.}

